\title{
Jesus and the law revisited
}

Author:

William R.G. Loader ${ }^{1,2}$

Affiliations:

${ }^{1}$ Department of Theology, Murdoch University,

Australia

${ }^{2}$ Faculty of Theology, University of Pretoria South Africa

Note:

Prof. Dr William R.G. Loader is participating as research associate in the project 'Biblical Theology and Hermeneutics', directed by Prof. Dr Andries G. van Aarde, honorary professor in the Faculty of Theology at the University of Pretoria, South Africa.

\section{Correspondence to:}

William Loader

email:

w.loader@murdoch.edu.au

Postal address:

52 The Circle, Warwick WA 6024, Australia

Dates:

Received: 04 Apr. 2010

Accepted: 15 May 2010

Published: 07 June 2011

How to cite this article: Loader, W.R.G, 2011, 'Jesus and the law revisited', HTS Teologiese Studies/ Theological Studies 67(1), Art. \#824, 6 pages. DOI: 10.4102/hts.v67i1.824
This article revisited the issue of Jesus' attitude towards the Torah on the basis of a critical discussion of the most recent extensive treatment of the theme by Meier in his A marginal Jew: Rethinking the historical Jesus: Volume four: Law and love (2009). It engaged Meier's contribution in the light of contemporary research, concluding that, whilst Meier provided an erudite analysis, his thesis that Jesus' teaching on divorce and oaths revoked Mosaic law did not convince, for it did not adequately consider the extent to which the contemporary interpretation of the Torah could encompass such radicalisation.

Andries van Aarde has established a deserved reputation across a wide range of scholarly endeavours, from the intricacies of New Testament exegesis to the broader issues of hermeneutics and public theology. This article takes as its starting point one of his areas of special interest, the historical Jesus. His Fatherless in Galilee: Jesus as child of God is a provocative and creative thesis that both attempts an explanation of the historical Jesus on the basis of his being brought up fatherless and reviews much of the research previously done on the historical Jesus. In his thesis, he engaged, amongst others, Meier's A marginal Jew: Rethinking the historical Jesus: Volume one: The roots of the problem and the person, which appeared in 1991, the first of his multi-volume series on the historical Jesus. This article seeks to honour Van Aarde by addressing Meier's latest volume, published in 2009, which addressed Jesus' attitude towards the Law: A marginal Jew: Rethinking the historical Jesus: Volume four: Law and love.

'Every other book or article on the historical Jesus and the Law has been to a great degree wrong'. So stated Meier's (2009:2) bold claim in his introduction. Meier was more inclined towards the position of Sanders (Sanders 1990:1-6, 90-96) than to that of the second quest, which saw Jesus rejecting the Law in some form, held by, for example, Conzelmann (1973:52-54, 59-67) and Käsemann (1964:38-39) and, to a lesser degree, Bornkamm (1960:96-100), Jeremias (1971:204-208) and Schweizer (1971:30-34). He argued, however, for a differentiated approach that explained how Jesus could both affirm the Law 'and yet in individual cases or legal areas (e.g. divorce and oaths) teach and enjoin what is contrary to the Law' (Meier 2009:3). He emphasised the complexity of the Jewish material, not least that now available from Cave 4 at Qumran, which had not been accessible to those scholars confident of Jesus' rejection of the Torah but also much else that belonged to the period, including the so-called pseudepigrapha and Philo and Josephus and enjoined appropriate caution in the use of later materials, such as rabbinic sources (Meier 2009:4). The introduction is replete with a careful discussion differentiating the historical Jesus research from the faith-based reconstructions of theology and edification and with a restatement of the criteria employed for historical reconstruction.

Similarly, the first chapter prepared for what followed; it identified the range of meaning of the Law and Torah, including illustrations of where rulings came to be cited as part of the Law, which, in reality, were specific applications or extrapolations of incidental references, such as on Sabbath warfare (Jos A.J. 14.63; cf. 12.276-277; 1 Mc 2:27-41;) and divorce (Mt 5:31-32; Jos A.J. 4.253; cf. Dt 24:1-4) (Meier 1991:33-37). One could have included here some instances of people advocating the Torah whilst, at the same time, propounding applications that contradicted its details in part, such as we find in the Temple Scroll (noted briefly on p. 127). With differences between what Jesus or any other Jew propounded and what the Torah required, we are left with assessing what such differences meant. Were they attempts to assert or reflect the assertions of individual claims to authority? Were they in any sense anti-Law or Law-critical or did the authors see themselves as seeking to ensure more thorough adherence to the Law's demands?

Meier (1991:79-80) first tackled divorce, noting its widespread practice as a male prerogative and the sparse allusions to it in the Old Testament. Deuteronomy 24:1-4 assumed purity law: the twice-divorced woman became taboo or defiled for the first husband. On the basis of the textual tradition of Malachi 2:16, which favoured permissiveness and the treatment in Philo and Josephus, Meier argued that the permissive assumption persisted that men could divorce on many grounds 
and argued that this was not in dispute (ibid. 81-83, 84-87). Perhaps Meier should have given more weight to Philo's moral twist to Deuteronomy 24:1-4 in Spec. 3.30-31, which, in turn, qualified his statement that it could be 'for any reason'. Meier's discussion underlined that Qumran material did not suggest that sectarians opposed divorce, as once supposed. The use of more recently published fragments would have enhanced Meier's argument, such as in the author's recent review of the discussion (Loader 2009:107-125). Meier argued for Paul's paraphrasing in 1 Corinthians 7:10-11 of what he believed was a prohibition by Jesus, perhaps known to him in more than one form (Meier 1991:100), for a $Q$ form of the saying behind Matthew 5:32 and Luke 16:18, looking more like the latter (ibid. 104-108) and for an independent witness in Mark 10:11-12, adapted, like Paul's, to a context where women also divorced (ibid. 108-112). The anecdote in Mark 10:2-9, now a Christian composition, may well have reflected discussion of divorce in Jesus' day, its pithy twopart aphorism preserving a saying by Jesus (ibid. 119-125). On the one hand, Meier rejected what he saw as anachronistic attempts to depict Jesus addressing issues arising from disputes between the houses of Shammai and Hillel $(m$. Git. 9:10) on the grounds of late sources (ibid. 94, 121, 126), even though they claimed to report on issues already topical before Jesus' time. On the other hand, Meier suggested that early rabbinic discussions of the wording of the certificate (ibid. 121-122, 124) suggested that matters of marriage and divorce might well have been under discussion.

For Meier (1991:126), Jesus' unthinkable, absolute prohibition on divorce was not grounds for claiming that Jesus abrogated or annulled Mosaic law but called for explanation. Appropriately, Meier noted that Jesus was not the only one to rewrite biblical law (ibid. 127); he could, however, have developed this further. Meier seemed reluctant to see Jesus' radical stance on divorce as an instance of the faithful observance of the Torah; instead, he suggested that Jesus' self-understanding as an eschatological prophet could also account for the phenomenon (ibid. 127-128).

Meier's (1991:123) discussion left me with further questions. As Meier observed, the Markan pericope had Jesus trump Deuteronomy with Genesis, noting that other Jews also used Genesis in relation to marriage issues. To what extent, however, is this another aspect of interpretation within the margins of Judaism? I am not convinced that one should make too much of the use of command and permit in the anecdote, where permit referred to divorce and command to the certificate (cf. ibid. 122).

Meier (1991:117) was apparently confident that Matthew's exception clauses were his or his tradition's later addition and changed the substance of the original. Some discussion of the possible impact of Roman law mandating divorce (Lex Julia de Adulteriis, $18 \mathrm{BCE}$ ), even though addressed to citizens, would have been helpful here and, more relevantly, expansion on what Meier noted as purity issues in Deuteronomy 24:1-4 (Meier 1991:79-80), such as we find in
Jub. 33:9, Test. Reub. 3:15 and Genesis Apocryphon 20.15 as well as in the infancy narrative of Mary and Joseph, namely that adultery rendered the woman defiled and that divorce or abstention from sexual engagement, amounting to the same thing, had to follow (similarly assumed in $2 \mathrm{En}$. 71:6). It could then be very probable, as Berger argued, that this would have been assumed and that Matthew or his community simply spelled it out rather than softening the command (Berger 1972:566-570; similarly, Loader 2005:118-120 and InstoneBrewer 2002:184-185, although less convincingly, as he sought to include further exemptions, for which there was no evidence).

Next, Meier turned to the saying prohibiting oaths, which he found doubly attested in Matthew 5:34-37 and Jacob 5:12. Whilst acknowledging a tendency amongst some Jewish groups not only to criticise false oaths but also to discourage oaths, Meier (1991:184-188) noted that there was no evidence of a Jewish group forbidding them altogether. Arguing that the two traditions reflected a real prohibition on the part of the historical Jesus, Meier saw this as a second piece of evidence, besides the divorce teaching, that Jesus 'presumed to revoke some institution or command of the Mosaic Law' (ibid. 205), explaining this as 'probably another example of the eschatological prophet proclaiming the rules of conduct binding on those who already live proleptically in the kingdom of God' (ibid. 206). Meier then asked us to consider whether we found Jesus 'revoking the Law in other areas' (ibid. 206). The formulation was unfortunate but it did reflect Meier's tendency to depict Jesus as revoking laws after the fashion of the second-questers rather than as radicalising the Law's demands in ways that made it even stricter and necessarily set some provisions aside. Meier mentioned but gave insufficient weight to Josephus' report that Essenes did not swear oaths (other than apparently before entering the society), regarding them as worse than perjury (B.J. 2.135).

Meier (1991) linked the two prohibitions, as he speculated:

As with the prohibition of divorce, so with the prohibition of oaths, Jesus' shocking teaching, which presumed to revoke some institution or command of the Mosaic law, probably evoked no little dissent and debate amongst his Jewish hearers.

(ibid. 205)

If such a teaching was a shocking abrogation of the Law, then one could expect to see evidence that it was widely accepted and assumed in the movement and that it did cause offence in its original setting. It was clearly, however, not widely assumed as Jesus' teaching; it would otherwise be hard to understand the presence of such swearing within the movement, which Meier (1991:199-200) noted, where there was certainly space and energy to correct and condemn those who did not conform. It could alternatively have been seen not as a shocking rejection of part of the Torah but as typical radicalisation, which could have occasioned controversy but would have been seen to fall within the margins of the Judaism of the time. The latter would be more likely and would explain why it later lacked the profile held by the divorce prohibitions. 
The extensive discussion of the Sabbath began with the important observation that no evidence existed outside the gospels in literature up to the time that indicated that healing on the Sabbath was a Sabbath breach (Meier 1991:240-249); only later did issues of healing on the Sabbath arise (such as $m$. Sabb. 14:3-4), when they were then disputed. With regard to the gospel narratives of healing on the Sabbath, Meier deemed all except the Johannine stories, which originally had no Sabbath references (ibid. 257-259), to be early Christian constructions (ibid. 253-257), although expanded with sayings that probably did go back to the historical Jesus (Mt 12:11 // Lk 14:5; Lk 13:15) and showed a commonsense approach to Sabbath halakhah, possibly even in direct contrast to Essenes and probably also Pharisees: 'It may well be that Jesus saw it as part of his teaching task to protect the common people from being attracted to sectarian rigorism' (ibid. 267).

Meier treated Mark 2:23-28 separately, tracing its development from the original 2:23-26 to its expansion, first by $2: 27$ and then by 2:28. He shared Sanders' view that the scene of Pharisees popping up in a grain field as incredible - the image of Midwest farming perhaps colouring his judgement (Meier 1991:274; Sanders 1990:20-21) - and exposed the flaws in the scriptural appeal to David at Nob (Meier 1991:275-277). Meier could have noted further that, in 2:23-24, hunger was not, in fact, the issue (in contrast to 2:2526 and Mt 12:1) but, on the formal grounds of 'distinction-yet connection' between Jesus and the disciples, he argued that 2:23-26 were a unity and, ultimately, were not authentic (ibid. 279). If the final 'christological trump card' (ibid. 280) was manifestly of Christian origin (ibid. 285-293), this did not need not be so of 2:27, which cohered in emphasis with the other sayings and with Jesus' appeal to creation in interpreting law and which preserved the aphoristic form typical of other sayings deemed authentic. Meier did, however, rightly note that 'the antithesis at the heart of the axiom must be understood as a 'dialectical' or 'relative' negation typical of Semitic speech' (ibid. 284). I do still find it more convincing to see 2:27 as the original response to a not so unlikely historical scenario to which, typically, scriptural argument (very messy and inadequate) had been added and to which, finally, the christological capstone celebrating Jesus' authority as Son of Man and fitting Mark's composition (1:22, 27; 2:10) had been appended, probably by Mark (Loader 1997/2002:51-52; Loader 2010:2749-2750).

Meier's (1991342-352): discussion of purity laws focused particularly on Mark 7:1-23. After a well-nuanced depiction of the diverse kinds of purity in biblical law and subsequent Jewish tradition, Meier turned to a careful analysis of the Markan passage, in which he exposed Markan and preMarkan Christian composition at work (ibid. 352-369), at most, holding open the possibility that the critique of the abuse of corban could have been derived from the historical Jesus (ibid. 369), to which, he noted, CD 16:15 provided a parallel (ibid. 379). Meier (1991) argues that:

the complex, artful, and artificial structure of Mark 7:1-23 reminds us that we are dealing with a multilayered Christian composition, not a videotaped replay of what Jesus said and did around A.D. 28.

Central to Meier's thesis was the status of Mark 7:15. He rightly pointed out the problems in supposing that Jesus made such an absolute statement, as he took it to be, both with regard to the setting of the ministry of Jesus, where it should have sparked outrage and to the early church struggling with food laws, where the absence of reference to it was scarcely inexplicable (Meyer 1991:392-394; Loader 2010:2752-2753). Left with Mark 7:15 as implausible on the lips of Jesus, Meier proposed that this arose some time after Paul's comments in Romans 14:14, although not directly dependent on it (Meyer 1991:394-395).

Meier noted the alternative of supposing that the saying was authentic and was to be treated as the kind of dialectical, relative negation that sometimes occurred in Semitic speech but he then declared this, without sufficient argument, as 'not necessary' and, somewhat inconsistently, went on to cite Mark 2:27 as an example of absolute use (387), whereas, earlier, he had cited it as relative (Meier 1991:284). Meier did acknowledge that 'the form of antithetical parallelism, by itself, does not tell us whether the statement should be understood in a relative or absolute sense' (ibid. 388) but then added that 'only an inspection of content and context can tell us that'. 'Context' here means the Markan context, which clearly demanded the absolute sense, although neither the 'content' nor 'context' in Jesus' ministry, which cannot be ruled out a priori, required this.

Once 7:15 was ruled out, certain consequences followed, including that 7:17-23 reflected secondary Christian explanation (Meier 1991:397-399), as, I believe, they did and changed the focus (Loader 1997, 1998:128, 2002:33-35). Cognency is lacking in Meier's (1991) suggestion that:

if the two-part aphorism of v. 15 comes from the historical Jesus, then there is a fair probability that the two-part explanation (vv. $18 \mathrm{~b}-23)$, which repeats and expands upon the language of v. 15, likewise comes from him, at least, in part, if not in total.

(ibid. 384)

Mark 7:1-5 served as a gateway to the passage and could not, Meier argued, have reflected the historical situation (Meier 1991:399-405). Booth's attempt to rescue this rationale by applying purity rules from much later rabbinic sources Meier rejected as anachronistic (Meier 1991:402-403; Booth 1986:189-203); he saw no plausibility in the assumption that Jesus could have come into conflict with other Jews over hand washing. Whilst agreeing with Meier's deconstruction of Booth's explanation, which I once shared (Loader 1998:133-134), I now interpret the proliferation of immersion pools and especially stone jars at archaeological sites in lower Galilee (Crossan \& Reed 2002:165-168; Freyne 2006:77; Reed 2002:43-46) as indicating a fairly widespread extension of the practice of ritual washing amongst the general population and not just amongst extremists (Kazen 2002:60-85; Regev 2004:388-389, who argued that the practice began to develop in pre-Hasmonean times). Perhaps the six stone jars of the 
Johannine tale of the wedding feast at Cana (Jn 2:6) provided confirmatory evidence that washing for purification before meals was such a practice (Deines 1993:267-275). One could then argue the plausibility that Jesus could have been confronted with having to respond to critique of his disciples not engaging in such practices and that he did so with a clever quip, playfully alluding to literal excretion and, in doing so, typically relativising concerns about ritual purity without rejecting them outright (Dunn 2003:576; Holmén 2001:237-246; Loader 2010:2751-2753).

Included in Meier's treatment of purity were some useful discussions on what proved to be dead ends, such as other allusions to purity issues: corpse impurity (Mt 23:27-28 // Lk 11:44; Mt 23:25-26 // Lk 11:39-41); female genital flow (Mk 5:35-34), women and menstruation; seminal emission and contact with 'lepers'. Meier interpreted the silence on these and others issues where Jesus was faced with issues of purity as indicating that 'for Jesus ritual purity is not only not a burning issue, it is not an issue at all' (Meier 1991:415). Elsewhere, Meier employed the argument that, had Jesus acted in a way that could have been seen as flouting a law, we would have seen some indication of this (ibid. 393). This would also have applied to issues of day-to-day purity, where observance would have been more probable than non-observance. Meier ended his chapter, however, with an appeal to the image of Jesus as a charismatic prophet who 'knows what he knows because he has, as it were, a direct pipeline to God's will' (ibid. 415) and that 'nothing more and nothing less explains what seems to us to be a patchwork approach to the Law on Jesus' part' (ibid. 415). There may have been more coherence than this suggested, coherence that fell within the margins of the Jewishness of the time.

Meier's final chapter addressed the love commandments. Meier gave particular attention to two, both of which he located with the historical Jesus: the double command to love God and one's neighbour (Mk 12:28-34); and the command to love one's enemy (Mt 5:44 // Lk 6:27). Meier also discussed the Johannine 'new commandment' (Jn 13:34) and the so-called Golden Rule (Mt 7:12 / / Lk 6:31). The latter he demonstrated as belonging to wider ancient Near Eastern tradition and, whilst this could also have been taught by Jesus, it fell significantly short in some ways of cohering with the first two and certainly did not originate with Jesus (ibid. 551-557). The Johannine saying and its related variants could have drawn on some memory of Jesus' teaching but it was clearly the product of a community that had developed its own christological rationale and that defined it to refer to its own (ibid. 558-572). The treatment of the first two sayings embraced a careful sifting of both Jewish and non-Jewish literature, which threw up some parallels and precursors, but nothing as striking and blunt (ibid. 501-522, 532-551).

Meier described Mark 12:28-34 as the 'odd duck' (Meier 1991:484) within the Jerusalem cycle, perhaps because Meier did not make the connection with the temple theme, which runs through Mark 11-13. It was not clear to me either that Mark was trying to emphasise that 'out of the massa damnata of the scribes, there comes forth one - and only one' (ibid. 489). Meier argued the case that, in this pericope, Mark was using tradition. In particular, Meier noted four elements as distinctive, (1) that both Deuteronomy 6:4-5 and Leviticus $19: 18 b$ were cited word for word, (2) that they were juxtaposed (using what later became known as the method of gěze $r a ̂$ šāwâ), (3) that they were ordered as first and second and (4) that they were declared superior to all others (ibid. $500,513)$. Meier noted that no other Jewish text at the time or before did the first, let alone the rest. Whilst I concur with Meier's caution about finding parallels in the Testaments of the Twelve Patriarchs, his discussion missed Test. Naphtali 8:7-9, which mentioned both commandments and ordered them in the same sequence (Loader 2005:158-159). Similarly, Meier's discussion of Jubilees missed the probable allusions to Deuteronomy 6:5 in Jubilees 1:15-16 and 23. Nevertheless, except in a fairly abstract sense in Philo, the Markan tradition was without precedent or parallel, even within the New Testament itself (Meier 1991:515). Whether this was enough to warrant attributing the connection to Jesus, it would certainly have cohered with material that Meier's research had deemed authentic up to this point. Here, Meier could have said much more about the corroboration of the stance of the tradition in Jesus' activity, which Meier (ibid. 481) treated all too briefly. Meier (1991) concluded that:

the criterion of discontinuity argues strongly that the historical Jesus taught the double commandment of love by binding together and yet ranking Deut 6:4-5 and Lev 19:18b and that this core teaching is reliably preserved in Mark 12:29-31.

(ibid. 519)

It could well be preserved in its original setting. Meier described it as a 'startling exchange' (Meier 1991:522), perhaps overplaying the sense of discontinuity. It could perhaps have been 'startling' not to those of its original setting but to Christians used to expecting confrontation and enmity.

What Meier described as 'the brutally brief direct command, "Love your enemies" ' (Meier 1991:529) had, at most, parallels in widespread traditions about dealing with retaliation and in occasional and exceptional commendations of not despising one's enemies (ibid. 532-551) but Meier argued nothing as succinct and uncompromising. Meier was careful to differentiate this command from commands about nonviolence and resistance. Much that appeared similar must be highly qualified, usually indicating self-interest, the will that God takes revenge on one's behalf or, in the case of Seneca and Epictetus, selective application (ibid. 546-548). The saying had no direct parallel in the rest of the New Testament either. Meier concluded that this was an instance where:

the historical Jesus seems to have gone out of his way to make some of his most disturbing or challenging teachings all the more disturbing by expressing them in brief, blunt formulations.

(ibid. 550)

These discussions allowed Meier (1991) to conclude that:

he historical Jesus did not simply use ad-hoc halakhic pronouncements on scattered topics like divorce, oaths, or the Sabbath. He did reflect on the totality of Torah and did extract 
from that totality the love of God and the love of neighbour as the first and second commandments of the Torah, superior to all others.

(ibid. 575-576)

However, he cautioned that this was still far from allowing us to conclude that he 'made love the hermeneutical key for interpreting the whole Law' (Meier 1991:576), imposing a Matthean grid on Jesus, which was questionable even as an adequate representation of Matthew (ibid. 576). The teaching on divorce might not square well with that.

In his concluding comments, Meier returned to what he called the bigger questions - 'Jesus and Torah, Jesus' parables, Jesus' self-designations, and Jesus' death' (Meier 1991:647) only the first of which, however, he tackled in his volume. Meier began by deploring the lip service given to the notion of 'Jesus the Jew' in recent American publications about Jesus, especially since 'from the 1970s onward, scholars such as Vermes, James H. Charlesworth, E.P. Sanders, and Jacob Neusner have hammered [an overused word throughout] home' its importance (ibid. 648). Similarly Meier affirmed 'no halakhic Jesus, no historical Jesus' (ibid. 648). This criticism was valid, although the claim was overstated given the relatively few instances that Meier could elicit of Jesus' halakhic engagement and given that, at least in the tradition of conflict stories, most conflicts over the Law were incidental and intrusive (such as Mk 2:1-3:6). Meier (2009:652) did indeed later note that the legal material traceable to Jesus was 'distressingly sparse and scattered'.

Meier's urging that we engage Jesus' stance at more than a theoretical level was salutary, as was his warning against trimming Jesus' teaching to acceptable ethical norms or homogenising it around the single principle of love (Meier 2009:649-651). Neither in Jesus nor even in Matthew do we have a system of morality and some of Jesus' judgements, such as on oaths and divorce, cannot easily be recast as versions of a love of neighbour (ibid. 651-655). Instead, Meier (ibid. 655) highlighted what he saw as the authority typical of the charismatic, which he depicted in a way that effectively - 'Amen I say to you' - carried a tone of 'it's so because I say it is so'. I was left wondering whether this, too, was an overreaction. Meier engaged in considerable speculation to ground this approach in Jesus' supposed interpretation of himself as the Elijah prophet, for which he saw a possible footing in the closing words of Malachi, which successively urged obedience to Mosaic law and announced Elijah's return (ibid. 656-657; Ml 3:22-24; ET 4:4-6). Meier bolstered his construction by reference to Elijah's halakhic role in later rabbinic literature and by hints that he detected in 1 Maccabees that people hoped that a coming prophet would help rule on what to do with defiled stones (1 Mc 4:46) and on how they should be governed (1 Mc 4:41) (ibid. 656). Meier acknowledged the speculation here, as he did that Jesus must have addressed many halakhic issues but that the records were lost (ibid. 652).

Missing from Meier's account was Jesus' attitude towards the temple cult, surely a core aspect of the Torah, where claims such as Jesus in the end deciding his own death could replace it or at least its sacrifices (Ådna 2000:439, 444-445;
Chilton 1996:115-123; Theissen \& Merz 1997:380-383) need addressing (Loader 2010:2755-2756), not to speak of the likely authentic material in which Jesus spoke of the temple and its leaders (Mk 14:58; Mt 23:37-39; Lk 13:34-35; Mt 23:34-36; Lk 11:49-51; Loader 1997/2002:95-122) and engaged in acts of provocation and prophetic judgement. We could expect these to follow in the next volume but they needed noting as an aspect of this volume's theme. The treatment of Jesus' attitude towards the Torah should also address his actions during his ministry, not only his words, as Sanders long ago rightly insisted (Sanders 1985:5-13), so that Meier's account remains only a partial treatment.

Meier's valid deconstruction of systems imposed on history could then have produced more networks of coherence. Meier did, however, provide painstaking attention to detail, combined with the interpretative generalisations that a good analysis requires, in what he addressed. At times, these did go beyond what I think the evidence required, especially when they elevated Jesus' teaching on divorce and oaths to a level that was shocking and offensive to his contemporaries, something Meier simply assumed and for which we have no evidence. Equally if not more likely was that Jesus' statements would have been seen as falling within the margins of contemporary Judaism, where enthusiasts of enhancing obedience to the Torah were not seen as renegades for demanding strictness that went beyond what the Torah allowed but rather as overly devout or extreme. Here, the article by Müller (1986), whom Meier (1991:47) cited otherwise with approval, provided an important corrective, including, I think, to Meier's construction. It would have been quite a different matter had Jesus espoused something in the opposite direction, namely dispensing with or watering down biblical laws, such as we find in the supposed conflicts over his Sabbath behaviour and in the early Christian conflicts amongst Jews over circumcision and the food laws.

This massive tome is an extraordinarily erudite discussion of key elements pertaining to Jesus and the Law, backed up with substantial bibliographies on all matters of relevance. The richest pickings are sometimes tucked away in extended footnotes, such as the footnote on whether women had the right to divorce (Meyer 1991:149-152, n. 38). It will serve future generations as an essential point of orientation for discussion on the issues.

\section{References}

Ådna, J., 2000, Jesu Stellung zum Tempel: Die Tempelaktion und das Tempelwort als Ausdruck seiner messianischen Sendung, WUNT 2 119, Mohr Siebeck, Tübingen.

Berger, K., 1972, Die Gesetzesauslegung Jesu: Ihr historischer Hintergrund im Judentum und im Alten Testament: Teil I: Markus und Parallelen, WMANT 40, Neukirchener Verlag, Neukirchen-Vluyn.

Booth, R.P., 1986, Jesus and the laws of purity: Tradition history and legal history in Mark 7, JSNTSup 13, JSOT Press, Sheffield.

Bornkamm, G., 1960, Jesus of Nazareth, Hodder and Stoughton, London.

Chilton, B.C., 1996, Pure kingdom: Jesus' vision of God, Eerdmans, Grand Rapids.

Conzelmann, H., 1973, Jesus, Fortress, Philadephia.

Crossan, J.D. \& Reed, J.L., 2002, Excavating Jesus: Beneath the stories, behind the texts, HarperCollins, San Francisco. 
Deines, R., 1993, Jüdische Steingefässe und pharisäische Frömmigkeit: Eine archäologischhistorischer Beitrag zum Verständnis von Joh 2,6 und der jüdischen archaologischhistorischer Beitrag zum Verstandnis von Joh 2,6 und der
Reinheitshalacha zur Zeit Jesu, WUNT 2.52, Mohr Siebeck, Tübingen.

Dunn, J.D.G., 2003, Jesus remembered, Christianity in the making, vol. 1, Eerdmans, Grand Rapids.

Freyne, S., 2006, 'Archaeology and the historical Jesus', in J.H. Charlesworth (ed.), Jesus and archaeology, pp. 64-83, Eerdmans, Grand Rapids.

Holmén, T., 2001, Jesus and Jewish covenant thinking, BIS 55, Brill, Leiden.

Instone-Brewer, D., 2002, Divorce and remarriage in the Bible: The social and literary context, Eerdmans, Grand Rapids.

Jeremias, J., 1971, New Testament theology: Part one: The proclamation of Jesus, NT Library, SCM, London.

Käsemann, E., 1964, 'The problem of the historical Jesus', in Essays on New Testament themes, pp. 15-47, SBT 41, SCM, London.

Kazen, T., 2002, Jesus and purity halakhah: Was Jesus indifferent to impurity?, ConB 38, Almqvist \& Wiksell, Stockholm.

Loader, W., 1997/2002, Jesus' attitude towards the law: A study of the Gospels, WUNT 2.97, Mohr Siebeck, Tübingen/Eerdmans, Grand Rapids.

Loader, W., 1998, 'Mark 7:1-23 and the historical Jesus', Colloquium 30, 123-151.

Loader, W., 2005, Sexuality and the Jesus tradition, Eerdmans, Grand Rapids.
Loader, W., 2009, The Dead Sea scrolls on sexuality: Attitudes towards sexuality in sectarian and related literature at Qumran, Eerdmans, Grand Rapids.

Loader, W., 2010, 'Jesus and the law', in T. Holmén \& S.E. Porter (eds.), Handbook of the study of the historical Jesus, pp. 2745-2772, Brill, Leiden.

Meier, J.P., 1991, A marginal Jew: Rethinking the historical Jesus: Volume one: The roots of the problem and the person, ABRL, Doubleday, New York.

Meier, J.P., 2009, A marginal Jew: Rethinking the historical Jesus: Volume four: Law and love, AYBRL, Yale University Press, New Haven.

Müller, K., 1986, 'Gesetz und Gesetzeserfüllung im Frühjudentum', in K. Kertelge (Hrsg.), Das Gesetz im Neuen Testament, pp. 11-27, QD 108, Herder, Freiburg.

Reed, J.L., 2002, Archaeology and the Galilean Jesus: A re-examination of the evidence, Trinity, Harrisburg.

Regev, E., 2004, 'Moral impurity and the temple in early Christianity in light of ancient Greek practice and Qumranic ideology', Harvard Theological Review 97, 383-411. doi: $10.1017 /$ S0017816004000768

Sanders, E.P., 1985, Jesus and the law, SCM, London.

Sanders, E.P., 1990, 'The synoptic Jesus and the law', in Jewish law from Jesus to the mishnah, pp. 1-96, SCM, London; Trinity, Philadelphia.

Schweizer, E., 1971, Jesus, SCM, London. (NT Library).

Theissen, G. \& Merz, A., 1997, Der historische Jesus, Vandenhoeck und Ruprecht, Göttingen. 